set in pairs, back to back, and providing accommodation for soldiers, with more spacious quarters for the centurions, was found to $b \theta$ in plan similar to those excavated in the south-west corner of the fortress in 1926-9. A coin of Nerva confirmed the date of their erection. Occupation by the Second Legion on this occasion appears to have been short; but in the third century the barracks were thoroughly renovated at a date indicated by the stamp "Leg. II Aug. Anto." as A.D. 212-222. Relics of the latest occupation, not necessarily of a military character, were found in the centurions' quarters, where a tile hearth had been built over a destroyed partition wall, and the moulded base of a column, upside down and partly sunk in the floor, appears to have served as a gaming-table, as several counters wero found around it. The associated layers contained fourth century coins and pottery of a late type. In all, 70 coins wero found and 90 legionary stamped tiles. Pottery was not abundant, but the most interesting find was a hoard of fivo gold coins, ranging from two of Nero, A.D. 55 and 61 to Titus and Domitian, A.D. 74 and 73 , which was found concealed in a barrack floor, and possibly represents the savings of a soldier, which was left behind when the legion was ordered north.

\section{Health Activities of the Rockefeller Foundation}

THE annual report for 1937 of the International Health Division of the Rockefeller Foundation, recently published, gives an account of the projects carried out under the auspices of the Health Division by members of its staff. Virus agents of yellow fever, influenza and other diseases, and cortain proteins, including visual purple, have been studied by the use of an analytical ultracentrifuge. By means of a cultured yellow fever virus, a vaccine has been produced with which some 60,000 persons have been inoculated, mostly in Brazil, tho results of which show that a practicable safe method of Iarge-scale immunization against yellow fever is now available. Studies on the epidemiology of the jungle form of yellow fever have also been pursued. Tuberculosis, particularly in Jamaica, hookworm disease in Egypt and tho United States, and malaria and its mosquito vectors in various countries, are other subjects that have been investigated. In addition to research work, the Foundation renders financial aid to State and local health services and to health education in all parts of the world. The report, which is very readable, includes soveral plates illustrating the work carricd out.

\section{The International Seismological Summary}

THE International Seismological Summary for July, August and September 1933 has just come to hand, containing details of the calculations of the initial times and epicentres of 169 earthquakes. Sixty-eight of these epicentres are new and 101 aro repetitions from old epicentres, showing the tendency of earthquakes to recur from the same epicentre. Included in the 169 earthquake shocks are 15 which had a focal depth below normal, the deepest being that of August 29, 1933, with epicentre $11 \cdot 0^{\circ} \mathrm{S}$.,
$69 \cdot 5^{\circ} \mathrm{W}$. (in Bolivia near its junction with Peru and Brazil) and focus 0.085 of the earth's radius below normal. Twelve of these deep focus shocks had their epicentres between $45 \cdot 4^{\circ} \mathrm{N}$., and $20 \cdot 5^{\circ} \mathrm{S}$. latitude, and between $131.5^{\circ} \mathrm{E}$. and $170 \cdot 0^{\circ} \mathrm{E}$. longitude, thus showing the deep-seated instability of this region of the earth which has Japan in its north-west corner.

\section{Milk for Mothers and Children}

A schene was prepared a short time ago by the Milk Marketing Board and approved by the Minister of Agriculture and Fisheries for the supply of cheap milk to local authorities, and was outlined in a circular issued by the Ministry of Health (Circular 1840. H.M. Stationery Office. 3d. net). The aim of the scheme is to enable expectant and nursing mothers and children under five, who cannot afford the full retail price for the milk they need, to obtain a pint of milk per head per day either free or for not more than twopence according to family circumstances. Those wishing to receive milk under the scheme will have first to apply to the local authority and they will then be told whether they are eligible to receive the supply. When authorized, they will ask an approved dairyman to deliver at their homo the milk to which thoy aro entitled.

\section{Announcements}

The remainder of the meetings of the British Association which began in Dundee on August 30 were cancelled on September 1. Most of the members present left Dundee on that day.

TuE French Academy of Medicine has awarded the Grand Prix Prince Albert $\mathbf{I}$ de Monaco to Jules Lefèvre, for his work on biology during the last fifty years.

ON the occasion of the jubilee of the Paris Pasteur Institute the scientific and executive committees of the Institute have awarded the gold Pasteur Medal to Dr. H. Plotz, of New York, and Prof. A. Saenz, of Montevideo, for their contributions to science.

IT is announced in Aesculape of May that three now chairs for the history of medicine have been founded in Italy, namely, at Florence, Turin and Sienna, while corresponding chairs in Rumania have been abolished.

DR. W. JuNK writes from The Hague to point out a mistako in Dr. W. T. Calman's review of tho British Muscum reprint of Linnæus's "Systema Naturae" (Nature, August 12, p. 269). The tenth edition was not, as there stated, the last published during Lin. næus's lifetime. The twelfth edition began publication in 1766, twelve years before the death of the author.

Arr the poisonous snakes and insects in the Zoological Gardens of the Zoological Society of London have recently been destroyed. Several of the more valuable animals have been sent to Whipsnade. The Zoo is again open to the public. 